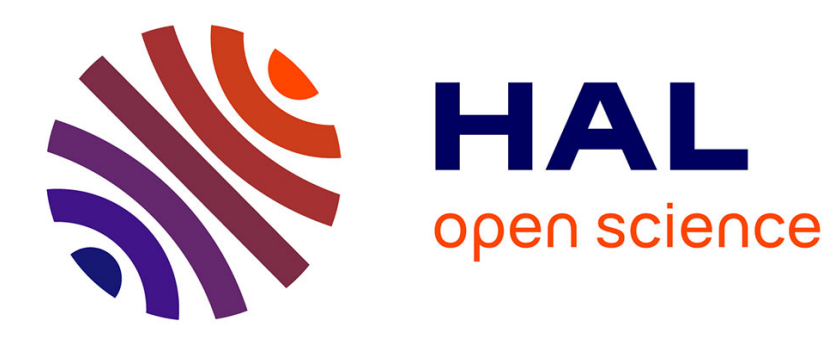

\title{
Exploring Continuities and Discontinuities Between Ælfric's and its Antique Sources
}

Fabienne Toupin

\section{To cite this version:}

Fabienne Toupin. Exploring Continuities and Discontinuities Between Ælfric's and its Antique Sources. Neophilologus, 2009, 94 (2), pp.333-352. 10.1007/s11061-009-9185-5 . hal-00568384

\section{HAL Id: hal-00568384 \\ https://hal.science/hal-00568384}

Submitted on 23 Feb 2011

HAL is a multi-disciplinary open access archive for the deposit and dissemination of scientific research documents, whether they are published or not. The documents may come from teaching and research institutions in France or abroad, or from public or private research centers.
L'archive ouverte pluridisciplinaire $\mathbf{H A L}$, est destinée au dépôt et à la diffusion de documents scientifiques de niveau recherche, publiés ou non, émanant des établissements d'enseignement et de recherche français ou étrangers, des laboratoires publics ou privés. 
author's name: Fabienne TOUPIN

title : Exploring continuities and discontinuities between Aelfric's Grammar and its antique sources

affiliation: Université de Tours (France), Laboratoire Ligérien de Linguistique (EA 3850)

personal address:

Dr Fabienne Toupin

10 rue d'Alger

37000 Tours

France

e-mail address: fabienne.toupin@ univ-tours.fr 


\title{
Keywords:
}

grammar; Ælfric's Grammar; Anglo-Latin education; late Latin Antiquity; transmission; vernacular; metalanguage

\begin{abstract}
:
This paper explores the extent to which the tenth-century English scholar Ælfric, author of a grammatical treatise known to us as Ælfric's Grammar, differed from his sources, the late antique grammarians Donatus and Priscian, (i) in his conception of grammar, (ii) in his perception of the structure of Latin, and (iii) in the descriptive apparatus he used.

I argue for the transmission of a conceptual framework. The facts taken into consideration are those dealt with by Donatus and Priscian, and they are analyzed with the help of the self-same concepts: Ælfric does not introduce new concepts into the description, nor does he elaborate or refine those transmitted by the grammatical tradition. I also note the transmission of a descriptive apparatus, at which level, however, discontinuity appears in the partial re-organisation of the treatise so as to gain coherence and pedagogical efficiency, in the Christianisation and Anglicisation of the exemplification, in the systematic translation of Latin items into English and in the coinage of a vernacular grammatical terminology. Yet in the most important form of discontinuity, i.e. in Ælfric's decision not to use Latin as the medium of a Latin grammar, several elements point to a continuity, such as the technical terms being Latin loan words or functioning as glosses to Latin words.
\end{abstract}




\section{Exploring continuities and discontinuities between Elfric's Grammar and its antique sources ${ }^{1}$}

\section{INTRODUCTION}

Ælfric (c.955-1010) was a priest and a monk, a pupil of Æthelwold who was one of the leading figures in the Benedictine reform movement in tenth-century England. In about 998 he wrote a grammar of Latin in English for monastic pupils. The text is generally known as Ælfric's Grammar, but is also occasionally referred to as Elfric's Excerptiones de arte grammatica anglice (see for instance Law 1997). It was probably the most sizeable grammar of its time and it rapidly achieved wide currency. It has two prefaces, one in English, the other in Latin, and comes with a bilingual Glossary and a Colloquy on Trades and Occupations meant to train young oblates to converse in Latin. ${ }^{2}$

Ælfric was not the first grammarian in Anglo-Saxon England. From the end of the seventh century Alcuin, Aldhelm, Bede, Boniface, Tatwine, and several anonymi had produced treatises of Latin grammar. But Ælfric's Grammar differs from these scholars' works in one major respect: it is the first grammar of Latin which uses the vernacular as its medium (Hurt 1972; Porter 2002). Such an innovation, radical though it is, has to be considered in relation to its cultural background: at the time that Elfric wrote his Grammar, English had been extensively used for literary purposes for three centuries.

Ælfric thus deals with categories, processes and terms of Latin grammar, but his metalanguage is English (that standard variety of Old English called West Saxon). Ælfric's decision was motivated by his desire to provide his young oblates with a grammar through which they would work their way first to the rudiments, then to a fluent command of Latin which would determine their ability to comprehend the Christian faith. Again, this purpose has to be set against a cultural context in which learning and Latin scholarship had been badly depleted by two centuries of Scandinavian raids on the monasteries.

This paper belongs to the intellectual tradition exploring the continuities and discontinuities in the transmission of grammatical knowledge between the late Latin Antiquity and the early Middle Ages. This transfer has been the subject of much scholarly attention (see in particular Law 1993; Lepschy 1994; Swiggers 1995), but it should be interesting to examine it in the light of the first grammar of Latin ever written in a European vernacular. I wish to emphasize from the start that in doing this I am not concerned with questions of originality nor of finding precursors - it would be irrelevant to frame the question in this way. Rather I wish to explore to what extent (and, if necessary, why) Ælfric, as an early medieval grammarian, differed from the grammarians of late Antiquity (i) in his conception of grammar, (ii) in his perception of the structure of Latin,

\footnotetext{
${ }^{1}$ I wish to warmly thank the anonymous reviewers whose comments and attention to detail improved the first draft of this article. I am particularly appreciative of their critical eye and helpful suggestions.

${ }^{2}$ Somewhat paradoxically, these three texts of Grammar, Glossary and Colloquy are referred to as "Ælfric's grammatical triad", as "a carefully designed pedagogical triad" by Hill (2007: 287), but have been demonstrated by the same author not to have functioned and not to have been transmitted as a grammatical triad in the eleventh century.
} 
and (iii) in the descriptive apparatus he used. ${ }^{3}$ I will adopt the conventional divisions of Antiquity and the Middle Ages into historical periods.

Whether Ælfric's Grammar is partially designed as a grammar of the English vernacular, in addition to being a grammar of Latin, is a relevant issue here, which I would like to briefly address before moving on to considerations of legacy.

\section{FLFRIC'S GRAMMAR, A GRAMMAR OF ENGLISH TOO? ${ }^{4}$}

Those scholars who have studied the Grammar disagree about whether Ælfric does teach English (cf. Menzer 2004: 108-09 for a detailed review). Some authors seem to think that such is the case (e.g. Lapidge et al. 1999: 8), an opinion probably backed by a famous passage in the Latin preface:

Ego Ælfricus, ut minus sapiens, has excerptiones de Prisciano minore uel maiore uobis puerulis tenellis ad uestram linguam transferre studii, quatinus perlectis octo partibus Donati in isto libello potestis utramque linguam, uidelicet latinam et anglicam, vestrae teneritudini inserere interim, usque quo ad perfectoria perueniatis studia.

(I, Ælfric, having only slight pretensions to learning, have taken the trouble to translate these excerpts from Priscian's Institutiones grammaticae for you young children into your language, so that once you have studied the eight word classes of Donatus's grammar in this book you will be able to incorporate both languages, Latin and English, into your tender minds until you arrive at more advanced studies.)

(Gneuss and Zupitza 2001: 1; translation Vivien Law's; emphasis mine)

echoed in the English preface:

I am not saying for all that that this book can bring much to teaching, nevertheless it will constitute an introduction to both languages, should it have the good fortune to please. (Gneuss and Zupitza 2001: 3; translation and emphasis mine)

Other scholars explicitly reject the idea:

His Grammar offers no systematic treatment of the morphology of Old English nor of its grammatical peculiarities. By utramque linguam Ælfric seems to have been referring to something else, namely that with the help of this grammar a pupil could at the same time acquire the ability to describe his own language in precise grammatical terms, drawing on the categories used for Latin [...]. (Gneuss 1990: 14) Undeniably, Ælfric's Grammar is interspersed with remarks on the vernacular. These might be adequately described as contrastive remarks. They are punctual and lexical in nature - they are mainly concerned with questions of vocabulary (Law 1997: 212), and there are very few insights into the structure of English. Here are a few examples:

\footnotetext{
${ }^{3}$ By which I mean the more methodological aspects of the work, mainly how it is organized into chapters and how information is set out in these chapters, the way grammatical points are exemplified by the grammarian, the method he employs for analysing the facts which are relevant in his conceptual framework, and the kind of metalanguage he uses.

${ }^{4}$ This article is not as such devoted to the debate about whether or not the Grammar teaches English, but as this heading states the main idea of Melinda Menzer's PhD dissertation and of several articles by her, it is especially relevant to refer to Menzer $(1996,1999,2004)$ for a comprehensive study of the question and an opinion different from that expounded here.
} 
(i) Elfric sometimes underlines a resemblance between the two languages, as when he remarks that the eight parts of speech of Latin are attested in English, without questioning the adequacy of this analysis for the vernacular:

Indeed, the whole of the Latin language is comprised in these eight classes, and English agrees with it in all these classes, as we have just briefly explained. (Gneuss and Zupitza 2001: 11; translation mine)

(ii) Conversely, his aim can be to point out that what goes for Latin does not necessarily go for English:

The sixth mode is used with the five others and it is always in the third person of the PASSIVvM: amatur: amatur a me 'I love', amabatur a me 'I loved', and so forth. But it is not very common in Latin and even less so in English. (Gneuss and Zupitza 2001: 134; translation mine)

The verb eo 'I go' (is 'you go', it 'he goes') has the forms iens 'going', euntis 'going' in the PARTICIPIVM, similarly queo 'I am able to' has the forms quiens 'being able to', queuntis, queunti in the PARTICIPIVM, and so forth. And all the verbs derived from the latter take $-e$ and $-u$ in the five inflected cases. Their future PARTICIPIVM is the following: iturus 'the one who wants or has to go'; quiturus, but we don't know of any equivalent in English for that form. (Gneuss and Zupitza 2001: 252; translation mine)

Elfric is aware that gender in nouns is not necessarily the same in Latin and in English, which is something of a problem because he translates all the Latin examples:

Know too that nouns are often of one gender in Latin and another in English. We say in Latin hic liber (masc.) and in English ðeos boc (fem.); in Latin haec mulier (fem.) and in English ðis wif (neuter), not ðeos; and in Latin hoc iudicium (neuter) and in English ðes dom (masc.), not ðis.

(Gneuss and Zupitza 2001: 19; translation Vivien Law's)

But strangely enough, the question of the case system elicits no comment on the two languages not being isomorphic. Old English, like Latin, is an inflected language which relies on changes in the form of a word to indicate grammatical function in nouns, and person, tense and mood in verbs. Thus Old English nouns, adjectives and determiners inflect for case the way these items do in Latin, except that the latter has six cases and the former just four (the nominative, accusative, genitive and dative cases). For this reason, among others, the description of Latin inflectional morphology cannot fit Old English, but Ælfric makes no observation about this. He focuses instead on establishing a semantic equivalence wherever possible: for instance, he uses a prepositional construction (preposition + noun phrase in the dative) as an equivalent to the Latin ablative.

Where they do occur, Ælfric's contrastive remarks are not systematic in nature. They certainly form no framework for the grammatical description of English, and it is impossible to find out how Ælfric perceived the structure of the vernacular from his description of Latin. I therefore do not endorse Hurt's opinion that the Grammar "illuminates his [Ælfric's] understanding of the Latin language, his conception of its relations to English, and thus his principles of translation" (Hurt 1972: 105). I think it is a misconception for a modern reader to interpret Ælfric's wish to have young children incorporate both languages, Latin and English, into their tender minds ("potestis utramque linguam, uidelicet latinam et anglicam, vestrae teneritudini inserere interim") as an intention on the part of the scholar to compare English with Latin. First, comparative grammar requires a theory of observables and a formal representation of languages, in which propositions explicitely derive one from the other in an ordered way. Such formalism, necessary to capture any kind of generalisation, is unknown to medieval linguistic thought. Secondly, Ælfric does not question whether the concepts and metalanguage he 
inherited from antique grammarians are relevant for the description of English - as a man of his time, he takes it for granted that they are:

The classical tradition leaves the Middle Ages and the Christian school the priceless legacy of an ars grammatica, of a complete metalanguage which was destined to be accepted as the most lucid and incisive instrument of intellectual penetration, the indispensable paradigmatic reference point for solving the most varied cultural quaestiones which clerics and lay scholars tirelessly pursued.

(Lepschy 1994: 139-140; emphasis mine)

On the whole, comparative grammar can be said to be foreign to Ælfric's interests, and accordingly I consider the Grammar as a grammar of Latin only. ${ }^{5}$

How much of this work, formally and conceptually, is inherited from Ælfric's sources and how much of it is original with the Anglo-Saxon scholar? My present concern about legacy makes it a necessary step to be now more specific about the derivative nature of Ælfric's Grammar.

\section{SOURCES FOR ALFRIC'S GRAMMAR}

Ælfric draws upon two grammatici of the Imperial period, Donatus and Priscian, and a later grammarian, Isidore of Seville. The most important influences are Donatus's and Priscian's.

Donatus (Aelius Donatus) lived in the fourth century AD and is known for two works: Ars Minor (Donati), a Latin grammar of the elementary type, and Ars Maior, a more elaborate treatise about three times longer. Priscian (Priscianus) is a sixth-century scholar who taught in Constantinople and wrote the immensely popular Institutiones Grammaticae. The work for which Isidore of Seville (c.570 - 636) is famous, Originum sive etymologiarum libri $\mathrm{XX}$ - often abbreviated as Etymologiae, is only partly about grammar: it is the first book, a text often copied in the Middle Ages, that deals with the art, and it does so from a Donatian point of view.

To be more precise, Ælfric's Grammar is based on the following three texts, presented in an ascending order of influence:

(i) The grammatical summary found in the first book of the Etymologiae, entitled "De grammatica." It is relevant only for the Grammar's last section, "Triginta divisiones grammaticae artis" (the thirty divisons of grammar).

(ii) Donatus's Ars Minor. In this respect Ælfric's Grammar belongs to a set of synoptic texts of elementary level, whose aim is to provide the student with the rudiments of Latin necessary to make one's way through a text - as opposed to the more elaborate grammars which are commentaries on Donatus's Ars Maior and whose object is to stimulate the reader's reflection (Swiggers 1995: 173-74).

(iii) Priscian's Institutiones Grammaticae. The Grammar has long been thought to have been compiled from the eighteen books of the Institutiones, but it has been established that Ælfric's starting point was in fact the Excerptiones de Prisciano (Gneuss 1990; Law 1997; Porter 2002). The text is an abridged version of the

\footnotetext{
${ }^{5}$ This opinion is at variance with Menzer's, who claims that Ælfric is teaching English grammar in his text, but by giving the expression teach English grammar a particular, specialized meaning: "To make an analogy to modern language instruction, we should not suppose that Ælfric wanted to teach Old English the way we do. Instead, writing for English speakers, he is teaching English grammar the way we teach introductory grammar or linguistics, making it possible for students to talk about their language grammatically. Ælfric's Grammar does teach English, not as other medieval grammars teach English, but as a textbook written for speakers of English teaches introductory English grammar." (Menzer 2004: 110; emphasis mine).

For recent studies of Ælfric's Grammar as a contrastive grammar, see Hill (2007, footnote 18).
} 
Institutiones Grammaticae incorporating material from other sources, and it might have been compiled by Ælfric himself (Porter 2002: 23-30; for counter-arguments cf. Hill 2007: 297). By making the Excerptiones, and therefore by making Priscian, the main source for his Grammar, Ælfric is in line with the main intellectual trend of his time.

Ælfric makes it clear that he is indebted to these grammatici, with the exception of Isidore of Seville, as early as the first sentence of the Latin preface:

I, Ælfric, having only slight pretensions to learning, have taken the trouble to translate these excerpts from Priscian's Institutiones grammaticae for you young children into your language, so that once you have studied the eight word classes of Donatus's grammar in this book you will be able to incorporate both languages, Latin and English, into your tender minds until you arive at more advanced studies.

(Gneuss and Zupitza 2001: 1; translation Vivien Law's)

The derivative nature of the text is ackowledged throughout, mainly by mundane, matter-of-fact expressions along the lines of "as Donatus/Priscian said", but sometimes by distinctively laudative turns of phrase such as "PRISCIANVS, who is considered the genius of the Latin language" or "master PRISCIANVS says it is necessary to distinguish...", and Priscian's name is even used in the exemplification (Gneuss and Zupitza 2001: 94, 111, 128). In view of Isidore's lesser influence on Ælfric, I will henceforth use the expression Alfric's sources to refer to the other two grammatici he drew upon, Donatus and Priscian.

\section{CONTINUITY ON THE CONCEPTUAL LEVEL}

What strikes the observer most is the general absence of new conceptual developments in Ælfric's work. The first continuity between Ælfric and his sources has to do with the autonomy of grammar from the study of the auctores.

\section{The aim of grammar}

Swiggers considers Graeco-Latin grammar as having no real unity except when considered in retrospect, from the point of view of the legacy that it constitutes. There is no real continuity, he argues, between the grammatike and the ars grammatica. Greek grammar remained a philological science throughout, a preliminary whose study was the key to the understanding and appreciation of literary texts, whereas in the works of the Latin grammarians from Donatus on grammar became an end in itself for reasons that have to do with the school system and the spreading of Latin in the Empire. This development gave rise to the production of manuals which could later be commented on. "Plusieurs de ces manuels ne visent que le niveau de l'instruction élémentaire et certains d'entre eux ont été conçus à l'usage d'un public grécophone (comme l'Ars grammatica de Dosithée [...])" (Swiggers 1995: 168).

Swiggers's opinion is not shared by the majority of linguists who have written about the Graeco-Latin world. In his major book on Donatus, Louis Holtz says that the grammaticus "considère l'explication des poètes comme sa tâche essentielle", and warns against "de graves erreurs d'interprétation si l'on ne considérait pas dans une même continuité grammaire grecque et grammaire latine. Il n'est peut-être même pas de domaine dans lequel les Latins soient plus étroitement tributaires des Grecs" (Holtz 1981: 74, 3). Most research into the history of linguistic ideas thus points out the philological nature of Graeco-Latin grammar when considered as a 
homogeneous whole. Latin grammars in particular are presented as being devised for students whose mother tongue is Latin (or at least for advanced foreign students). ${ }^{6}$

If we follow Swiggers, then Ælfric has a common point with his sources. The grammar Ælfric and his predecessors are engaged in is an autonomous discipline, detached both from rhetoric and dialectic with which it formed the classical trivium. Grammar becomes even more of an end in itself with Ælfric, whose pupils contrary to Donatus and Priscian's - were not members of an urban Latin-speaking community and were not likely to have attended primary classes:

Natural language change, on one hand, and an influx of non-native speakers, members of Germanic tribes, on the other hand, meant that the grammatici could no longer assume a knowledge of the forms and syntax of the language of Virgil and Cicero on the part of their pupils. Instead of being a preliminary to the appreciation of Classical verse and oratory, the study of grammar became an end in itself. (Law 1986: 368; emphasis mine)

Therefore Ælfric's first concern is to supply the monastic pupils with a practical instrument for learning Latin: "Ælfric is not concerned with training budding poets in the mysteries of the Latin hexameter" (Law 1997: 207). Yet, neither in Ælfric's treatise nor in the Ars Donati and the Institutiones Grammaticae is grammar perfectly autonomous. One distinguishes the outline of a higher aim, which for Donatus and Priscian is the knowledge of the auctores (Virgil, Terence, Cicero, ...), and for Flfric the knowledge of the holy texts of Christianity. For the English scholar, just as for the Carolingian tradition that he drew upon, "[t]he goal of grammar was an enhanced understanding of the Word of God as made manifest in the Latin Scriptures" (Law 1997: 140). This goal Ælfric makes plain in his English preface:

It is therefore important now to warn the monks and the servants of God against the waning of sacred teaching or its abandonment in our days, as was the case several years back in England when no priest was any longer able to write or decipher an epistle in Latin, until Archbishop Dunstan and Bishop Æthelwold re-established this teaching in monastic life. (Gneuss and Zupitza 2001: 3; translation mine) Elfric's higher concern is therefore with the correct understanding of the Latin Scriptures and the avoidance of error, OE gedwyld, a term by which he is said to have often meant 'heresy' (Hill 2007: 299). "Grammar, in other words, underpinned orthodoxy [...]" (ibid.).

\section{Grammar is not a speculative discipline}

Another form of continuity can be observed on the conceptual level between Ælfric and his sources. The (more or less) autonomous grammar they are engaged in is a knowledge of facts, not a speculative discipline. What Swiggers says of antique grammar:

[S]i elle donne lieu à des réflexions plutôt spéculatives (par ex. sur le rôle de l'analogie ou de l'anomalie dans la langue), ce n'est qu'en fonction de convergences ou de divergences qu'on observe entre des formes qui ont été réunies en paradigmes, ou qu'on observe entre une forme et un sens (par ex. un pluriel pour un objet singulier, un nom féminin ou masculin pour un inanimé). (Swiggers 1995: 161) is also true of Ælfric's Grammar, which is a catalogue of facts:

\footnotetext{
${ }^{6}$ It is the case for instance in Law (1986: 365-80), or in Gneuss (1990: 9): "The Anglo-Saxons had to learn Latin as a foreign language. Vivien Law has rightly stressed how unsuited the late Roman grammatical works were to this task, since they had been written for native speakers." (emphasis mine).
} 
[...] for the first time Europe's most precocious vernacular, English, became a vehicle for linguistic explanation, a medium to convey a collection of facts about Latin, the language of school and scripture. Practical classroom concerns thus dictate the form of the Grammar, and the result is a full presentation of the basic facts of Latin accidence and vocabulary, in clear, logical order and in accessible form." (Porter 2002: 1, 31; emphasis mine)

\section{The object of grammar}

Spoken language is outside the scope of grammar thus defined. Where Donatus and Priscian are concerned, this is due to a difference which had appeared between Greek and Latin grammar, the latter diverging from its Greek model by the reduced importance of prosodic and metrical phenomena (Swiggers 1995: 165-66). The difference is only more marked in their works than in most of their predecessors'. In Ælfric's Grammar, the issue of the pronunciation of Latin is not addressed, somewhat paradoxically, considering that its importance is underlined in the preface:

Sciendum tamen, quod ars grammatica multis in locis non facile anglicae linguae capit interpretationem, sicut de pedibus uel metris, de quibus hic reticemus, sed aestimamus ad inchoationem tamen hanc interpretationem parvulis prodesse posse, sicut iam diximus. Miror ualde, quare multi corripiunt sillabas in prosa, quae in metro breues sunt, cum prosa absoluta sit a lege metri; sicut pronuntiant pater brittonice et malus et similia, quae in metro habentur breves. Mihi tamen uidetur melius inuocare deum patrem honorifice producta sillaba, quam brittonice corripere, quia nec deus arti grammaticae subiciendus est.

(One must yet acknowledge that in many instances Latin grammar doesn't easily lend itself to interpretation in the English language: for example where feet and meters are concerned, a subject that we leave aside here. Nevertheless, as an initiation, our version seems to us to be of help to young beginners, as we have already said. Many, to my astonishment, shorten in prose syllables which are indeed short in verse, but prose is not governed by metric. Thus they pronounce pater, malus in the British way, whose vowels are considered short in verse. It seems to me preferable, though, to invoke God the father by articulating the syllable pompously rather than shortening it in the British way, even though it is true that God couldn't possibly be subjected to the laws of Latin grammar.)

(Gneuss and Zupitza 2001: 2; translation and emphasis mine)

Porter's following comment on Priscian's Institutiones: "[...] surely no non-Latin speaker ever learned colloquial language from it" (Porter 2002: 11) probably goes for Ælfric's Grammar too, except that it is supplemented by the Colloquy whose aim was precisely to train young oblates to converse in Latin.

Also outside the scope of grammar is syntax, another feature common to Ælfric, Donatus and - to a lesser extent - Priscian. Antique grammar had not set up the notions of agreement (congruitas) and government (rectio), which are central in syntax. In the works of the grammatici in general, syntactic theory is underrepresented, not to say altogether absent - a systematic treatment of syntax will not be found before the twelfth century. In Priscian's Institutiones one finds the concepts of sentence structure and word order, but already in the Excerptiones, which is Ælfric's direct source, "the higher theoretical studies on syntax have largely gone by the board." (Porter 2002: 13) 
Witness to the status of syntax in Ælfric's Grammar is a particular technical term, namely word. Just like the Biblical verbum, word means both 'word' and 'verb' ('word' is the initial meaning while 'verb' is first attested in Ælfric's work). But the most remarquable feature of word is its ability to refer to all possible syntactic levels. Bosworth and Toller (s.v. word II) define it thus: ${ }^{7}$ "a word, a group of words forming a phrase, clause, sentence or sentences." The meaning of word covers the entire semantic field that modern linguistics marks out with phrase, clause, sentence and discourse. ${ }^{8}$ This is not so much due to an extraordinary semantic versatility as to the lack of distinction in Ælfric's description between the different syntactic levels: the scholar goes into an enormous amount of detail concerning the morphology of the eight parts of speech but is not concerned with syntax. This does not imply that the notion of hierarchy is unknown to Ælfric. The backbone of his conception of language is indeed a hierarchy of four units, but in accordance with the whole antique tradition which he inherited these units are letter, syllable, word and sentence, not phrase, clause, sentence and discourse.

The fact that prosodic, metrical and syntactical facts fall outside the scope of grammatical knowledge benefits the description of morphology. Morphology - more precisely inflectional morphology - can even be said to be over-represented in the works under consideration here. Porter writes of Priscian's Institutiones that "[b]eyond the sheer size of the work, there is an enthusiastic emphasis on morphological oddities" (Porter 2002: 11). Such emphasis is also apparent in Ælfric's Grammar: out of the 296 pages of Zupitza's edition, 280 (94\%) are dedicated to the eight parts of speech and their accidents.

Combined with the conception of grammar as a knowledge of facts, morphology's inflated importance has two main consequences:

(i) on the form of the work. Ælfric's Grammar can be seen as an enumeration of forms functioning as paradigms and inserted into a continuous text. The following comment by Holtz on the Carolingian material fits this treatise: it is not the notion of system that prevails in it but that of standard (Holtz 1988: 139-40). By this I no more than Holtz imply any (anachronistic) criticism, merely that the grammarian's preoccupation is with the description (and preservation) of the standard forms of Latin, not with the structure of language in the abstract, cf. the antique formula Grammatica est scientia gnara recte scribendi et recte loquendi (the skilful art of writing and speaking correctly).

(ii) on the structure of the work. This is the question I now wish to address.

\section{Structure of the work}

The structure of Ælfric's Grammar is that of the artes grammaticae, which here again differ from their Greek model by the reduced importance of prosody and metric together with the inflated role of morphology. This structure is as follows:

I. Preliminaries (analysis of the vox articulata)

II. Reading, prosody and metric (letters/syllables/measure/accent/punctuation)

III. Morphology: the eight parts of speech

IV. Rhetoric and normative stylistics: barbarism, solecism, metaplasm, figures of speech.

Greek as well as Latin grammarians set great store by the order in which the parts of speech were enumerated (Holtz 1981: 64). A fixed order of presentation had been adopted as early as the Hellenistic period;

\footnotetext{
${ }^{7}$ The dictionary is hereafter cited as BTS.

${ }^{8}$ Finally "anything said, words" seems by far to be the best definition of the term (BTS, s.v. word IIa).
} 
but the grammatici, having on the one hand done away with the article (an unknown part of speech in Latin) and on the other hand added the interjection (by dividing the adverb into adverbium and interiectio), had three types of lists circulating. Adopting a specific order amounted for the grammarian to declaring the school he belonged to. The order used by Ælfric corresponds to what Holtz calls the $\mathrm{d}$ order, spread by the Ars Donati and different from the p order which was characteristic of Priscian and was used in the Greek technai (Holtz 1981: 64-69; Swiggers 1995: 165-66). The d order has an advantage in terms of memory, by associating noun and pronoun, verb and adverb. ${ }^{9}$

Donatus's Ars, like Priscian's Institutiones, pertains to the genre called Schulgrammatik in Law's typology (Law 1986), which means that each part of speech is dealt with in a section comprising a definition in semantic terms, an enumeration of the properties of the part in question (its accidents), and a treatment of each property. Ælfric adopts the same organization. In his Grammar the definitions of the verb, the participle and the interjection come from Donatus; those of the pronoun and the adverb, from Priscian; the definitions of the conjunction and of the preposition are an original contribution of the author, inspired by both his sources (Hurt 1972: 109). Porter has noticed an increased coherence from the Institutiones Grammaticae to the Excerptiones de Prisciano and finally to Ælfric's Grammar:

In terms of coherence, the Excerptiones compares favourably with Priscian's originals. Where Priscian's discussion of a topic may ramble over two or more books of the Institutiones, or between separate treatises, the Excerptiones will often gather these together in an unbroken treatment. This advantage is palpable. Law has called the Excerptiones' organizational innovations a simplification, which is certainly true, yet the added coherence and continuity are also a major improvement. [...] And despite the organizational modifications to the Institutiones, the superior arrangement of Ælfric's Grammar shows that the Excerptiones still left room for improvement (Porter 2002: 12-13).

While sticking to Donatus's d order for the eight parts of speech, in each of the eight sections Ælfric gathers together the discussion of a given topic, syntactic category or lexical item. He compresses or altogether omits useless lists of examples or the kind of information of secondary importance that can be the object of tedious commentaries by Priscian (Hurt 1972: 109; Porter 2002: 31; Law 1997: 204-05). He thus skilfully shortens several lengthy passages, for instance: "In fact all the nouns that derive from other nouns are called DENOMINATIVA, and their number is almost incalculable." "We won't say any more here concerning verbs and hope this will prove to be of some usefulness." (Gneuss and Zupitza 2001: 18, 222; translation mine).

From this comparison on the conceptual level between Ælfric's Grammar and both the Ars Donati and the Institutiones Grammaticae, it can be concluded that the grammarians' conception of grammar and perception of the structure of Latin are on the whole identical, and that there is no conceptual renewal in the transmission process. Discontinuity is rather found in grammar's descriptive apparatus.

\section{CONTINUITY AND DISCONTINUITY IN GRAMMAR'S DESCRIPTIVE APPARATUS}

\section{Method for analysing and setting out the facts}

\footnotetext{
${ }^{9}$ By contrast, the advantage of the $\mathrm{p}$ order is in the grouping together of the declinable categories before the indeclinable ones.
} 
It is a difficult task to compare the method of analysis used by Ælfric with that of his sources, insofar as none of the scholars is explicit about it. In particuliar, the procedures for identifying morphosyntactic units are not stated, these units being taken for granted.

The method for setting out the facts used by Ælfric does not differ from Donatus's or Priscian's or, more broadly speaking, from the grammatici's. On the theoretical level, as has been said, one finds an enumeration of forms functioning as paradigms (as much as glossaries) and indicating the prevalence of the notion of standard. On the didactic level, the approach is more teaching- than learning-centred: knowledge is declarative in nature, magisterial and not procedural, as is to be expected at the time.

Discontinuity is to be found elsewhere in the apparatus. Culturally, Ælfric's students are not similar to those of Donatus or Priscian. Not only is Latin a second language for them, but imbued as they are with the monastic ideal, the Classical spirituality and culture have also largely become foreign to them. This makes it necessary for the grammarian to christianise the exemplification and give it a strong local colouring, to translate all Latin items into English, and to resort to the vernacular as the medium of grammar, i.e. to use English technical terms.

\section{Christianisation and anglicisation of examples}

The exemplification shows both continuity and discontinuity between Ælfric and his sources. Continuity is due to the fact that medieval grammarians do not consider it a necessity to be original in their choice of examples. Bunches of examples are obviously handed down from grammar to grammar and from glossary to glossary. Thus the first example quoted in the Elfric's Grammar is the beginning of the Aeneid: "Any sound is either intelligible or indistinct. Intelligible is a sound emitted meaningfully, such as arma uirumque cano 'I sing of arms and the man'." (Gneuss and Zupitza 2001: 4; translation mine). Virgil is named several times and his heroe Aeneas illustrates the noun of the first declension ending in -as.

Yet, there is no reference whatsoever to the authors from whose works the exemplification is excerpted. No names, no titles: all examples are anonymous, one is not to know whether a verse is by Ennius or Virgil. Interestingly, in that separation with the auctores there is continuity too - continuity with the Ars Donati. Holtz has noted that while other Latin grammarians sometimes mention the author, sometimes not, Donatus introduces a more systematic practice, consisting in never mentioning him:

Elle [cette pratique] a pour effet de rendre moins fondamental le lien entre analyse linguistique et exégèse des auteurs. Il s'agit toujours, au moins virtuellement, de citations poétiques, mais ce qui compte c'est moins le recours à l'auctoritas que l'évidence que l'exemple proposé, quel que soit son auteur, illustre de façon adéquate la notion à laquelle il s'applique. (Holtz 1981: 120)

Incidentally, this seems to lend weight to Swiggers's position that there is no continuity between Greek and Latin grammar because the grammatike always remained a philological science, while in the works of the grammatici from Donatus on grammar became an end in itself. Holtz does not endorse that view, having argued earlier (in 1981) that it would be a gross misconception not to consider Latin grammar as the continuation of Greek grammar, and that there was probably no other domain in which Latin scholarship was more heavily indebted to the Greeks (see above).

There is probably another explanation for the separation from the auctores. I have already stressed that the notion of standard prevails in Ælfric's Grammar. Ælfric is concerned with teaching corrrect language and 
having his monastic pupils master correct usage in due course. But many of the linguistic features so dear to the poet are considered to be faults from a formal grammatical point of view; a grammar's linking of the poets and corrrect usage is, in that respect, untenable. And to crown it all, the difficulties inherent in using literary works composed several centuries before as the basis of correct language are bound to multiply as the historical distance between ancient text and medieval reader increases (such difficulties were necessarily encountered by Donatus and Priscian well before Ælfric's time).

Discontinuity is apparent in Ælfric's Christianisation of the exempla. More specifically, Christianisation consists in introducing references to the Vulgate, the Church Fathers, and the Christian poets. Once again, there is not so much real discontinuity in this as the intensified continuation of a process initiated earlier. Vivien Law argues that the Christianisation of pagan examples occurred as early as the fifth century: "In Priscian and Pompeius we find a few Judeo-Christian examples: Augustine's Ars breuiata contains several details which point to a Christian context, along with many examples from Cicero and Virgil" (Law 1986: 367; see also Holtz 1981: 256-58). This suggests that the Christianisation of examples may also have been linked to an awareness of the linguistic differences between Virgil's Latin and the Vulgate's.

Elfric introduces the names of Æthelwold, Dunstan and Bede (among others) alongside the Classical characters; in a discussion of the second-declension vocative, the names of two saints (Laurence and Maurice) are added and that of Terence is omitted. Christianisation is especially noticeable in a section on jurative adverbs (i.e. swear adverbs). Ælfric refuses to use Priscian's adverbs (Hercle et Mediusfidius) or to substitute Christian adverbs for them; he classifies the preposition per in juro per deum or per meum caput as a jurative adverb and thus concludes:

But Christ himself has forbidden us to swear and told us to confirm our words in the following manner: est? 'is it so?', est 'it is so', non? 'is it not so?', non 'it is not so'. There are other ADVERBIA that are used for swearing, but why mention them since we are not allowed to swear?

(Gneuss and Zupitza 2001: 227; translation mine)

However, Ælfric's christianized treatise is not comparable to the Ars Asporii, a Latin grammar written by a seventh-century Irishman called Asper, whose examples refer exclusively to the monastic environment. Christianised and Classical exemplification coexist in the Grammar.

Similarly, the topics chosen for the exemplification are given a Christianized and an Anglicized colouring. Vivien Law has remarked on the choice of citharista 'harpist' as the model for the first-declension masculine paradigm, which reflects the importance of the hearpere in Anglo-Saxon society (see Law 1997: 20810 for a very detailed presentation of the issue discussed here). Besides, the king - and the queen to a lesser extent - is given a prominent place in the exempla. Maybe the king summons the theme of the comitatus heroic code, which was central in the pre-Christian Germanic culture and still very much alive in tenth-century AngloSaxon society. ${ }^{10}$

Next to the king, the bishop is the most important local character, and the pair of king and bishop (i.e. rex and episcopus) serves several times to illustrate grammatical points, such as the second- and third-declension paradigms. Here Christianisation and Anglicisation go hand in hand. According to Crépin (1985: 88), Christianization is also apparent in the fact that despite occasional references to the family, Ælfric's Grammar

\footnotetext{
${ }^{10}$ The code is based on the idea of absolute loyalty vowed to a lord by his followers, see Lapidge et al., 1999, s.v. comitatus.
} 
does not dwell on this aspect of Germanic society, focusing much more on the monastic community than on flesh-and-blood family ties. Eventually, after King Edgar and Bishop Æthelwold, Ælfric himself steps in, his name appearing in a passage exemplifying the use of personal pronouns (Gneuss and Zupitza 2001: 8). When he uses his own name, Ælfric is merely emulating most Latin grammarians, in particular Priscian (Holtz 1981: 110 and footnote 19).

To conclude, the exemplification - the examples proper and the topics chosen - is infused with three clusters of ideas and values which Hurt characterizes as central on all levels in tenth-century Anglo-Saxon life: the Classical heritage, the pre-Christian Germanic heritage and the Christian heritage.

\section{Translation of all Latin items into English}

Ælfric's students being imbued with the monastic ideal, Classical spirituality and culture have become largely foreign to them. The translation of Latin items into English is therefore necessary and takes a systematic turn, although Ælfric sometimes gives more of an explanation than a translation, for instance when dealing with mythology: "haec Dido: anes wifes nama 'Dido, name of a woman'." (Gneuss and Zupitza 2001: 37).

\section{Technical terms ${ }^{11}$}

The most important discontinuity between Elfric and his sources is in the medieval scholar's decision not to choose Latin as the medium of his grammatical manual but the students' native language, English. The coinage and use of vernacular technical terms shows Ælfric's preoccupation with comprehensibility. The scholar is a master teacher whose work is meant for young pupils not yet able to cope with Latin, as stated in the Latin preface:

Noui namque multos me reprehensuros, quod talibus studiis meum ingenium occupare uoluissem, scilicet grammaticam artem ad anglicam linguam vertendo. Sed ego deputo hanc lectionem inscientibus puerulis, non senibus, aptandam fore.

(I know that many people will reproach me for having chosen to occupy myself with such studies, i.e. translating grammar into English. But I consider this subject to be suited to ignorant children, not to greybeards.) (Gneuss and Zupitza 2001: 1; translation Vivien Law's)

That the pedagogical viewpoint should prevail over all other considerations marks a continuity with the Ars Donati (Holtz 1981: 93 sq).

The vernacular terminology, like the christianized exempla, also testifies to Ælfric's conception of the ultimate end of grammar: "Ælfric's decision to translate a Latin grammar into the vernacular is entirely consistent with the thrust of his life's work: to provide a body of literature through which the monk or nun with only a scanty knowledge of Latin could none the less come to comprehend the Christian faith" (Law 1997: 203).

In addition to being a master teacher Ælfric can be described as a master terminologist who works his way from the notion to the term by implementing two universal methods for enriching the word-stock of languages, borrowing and neology. What loan words he uses come from Latin while most neologisms are loan

\footnotetext{
${ }^{11}$ A number of studies have been dedicated to Ælfric's grammatical terminology; apart from articles by Williams (1958), Gneuss (1990) and Toupin (2005: 203-62), one should be referred to two unpublished PhD dissertations: Shook (1939) and, more recently, Bender-Davis (1985).
} 
translations of Latin items. Continuity (in the prevalence of the pedagogical point of view, in the more or less overt presence of Latin terms) therefore subtly mingles with a major discontinuity residing in the choice of a vernacular as the medium of a Latin grammar. The group of metalinguistic terms borrowed from Latin is the least numerous. I will deal with them first.

A) Loan words

Ælfric makes use of three loan-words: part ( $<$ Lat. pars), casus ( $<$ Lat. casus) and declinung ('case' or 'inflection, declension').

The masculine noun casus is the insular adoption of Lat. casus, likewise a masculine noun. It is impossible to hypothesize an accidental resemblance between the two words, because OE casus is not attested anywhere in the whole of the Old English corpus apart from the Grammar. There is no such English verbal stem as $\mathrm{OE} *$ cad- meaning 'fall' (cf. Lat. cadere); the Old English for 'fall' was feallan. Declinung is a quite different case, representing the native derivational suffix -ung added to a Latin base.

From a morphological point of view, loan words behave in accordance with the rules of Old English grammar (e.g. if they are in the dative, it is indeed the English dative form they take and not the Latin one). The same does not hold for the majority of Latin technical terms found in the Grammar, e.g. ABLATIVVM: theirs is still the morphological behaviour of Latin words. Therefore they cannot be considered as loan words but as mere substitutes in Latin of items available - or potentially available - in English.

B) Neology

Neology is the terminological method most resorted to by Ælfric. It makes it possible, among other things, to coin units by the technique of loan translation, that is by translating morphologically complex Latin words or phrases element-by-element, in compliance with Old English morphosyntactic constraints. Ælfric's translation of Lat. sub-auditio by under-hlystung ('implying something' or 'retrieving [missing] words') is typically a loan translation. It is a perfect one-to-one (morpheme-for-morpheme) correspondence - in both cases a preposition meaning 'under' is followed by a deverbal noun derived from the verb meaning 'hear'.

Ælfric's Grammar hosts numerous such loan translations: all the names for the parts of speech (e.g. fore-set-nes «preposition», Lat. prae-posi-tio) and the various modifiers that apply to them (for instance, concerning prepositions, the adjective gesprac(e)-lic, which is usually translated by 'inseparable' but really means 'discursive', being a loan translation of Lat. loquela(r)-is); the names for sound units, all the names indicating case, gender, number, tense or mode (e.g. under-ðeod-endlic 'subjunctive', Lat. sub-iunc-tivus) are thus formed, which testifies very clearly to the crucial role played by loan translation in the coinage of AngloSaxon grammatical terminology.

The question is how far loan translation can go. Are morpheme-for-morpheme translations always lexical in nature? I have no definite answer to this, but would like to mention two different cases:

(i) The first seems to be the loan translation of a suffix ending. The double suffix -end-lic (e.g. wregendlic 'accusative') represents in most cases a calque of Latin -t-ivus. ${ }^{12}$ The OE inflectional suffix -end(e) marks the present participle and forms an agentive noun, like the corresponding Lat. -tor; the OE derivational suffix -lic translating Lat. -ivus derives an adjective from the noun.

\footnotetext{
${ }^{12}$ A high-frequency item in the Grammar, this double suffix is not specific to Ælfric (see for example berendlic 'tolerable' and wemmendlic 'which corrupts').
} 
(ii) The second is apparently a syntactic calque concerning the valency pattern of a verb: ateorian, whose nontechnical sense is 'fail, become weary, cease, leave off', is an intransitive verb according to the data provided by BTS. But in Ælfric's text the verb is used transitively, as attested by its complement "sume":

ealswa gæð hoc genu pis cneow ET PLVRALITER haec genua; hoc gelu pes forst, ueru spitu, specu scræf, pecu nyten, testu crocscerd, penu heddern ET CETERA, ac hi ateoriað sume on menigfealdum getele.

(The same goes for hoc genu 'this knee', ET PLVRALITER haec genua; hoc gelu 'this frost', ueru 'broach', specu 'cave', pecu 'cattle', testu 'potsherd', penu 'store-house', ET CETERA, but they lack some [forms] in the plural.) (Gneuss and Zupitza 2001: 80; translation mine)

Are the lexicographical data concerning ateorian incomplete? Or is this a syntactic calque of the pattern of Lat. deficere, a verb which is both transitive and intransitive? Loan translation of morphologically complex Latin words or phrases sometimes yields impossibly clumsy results, some of which might even be described as tongue-twisters, for instance Lat. interiectio > OE betwuxaworpennys.

A good many technical terms are not loan translations but originally non-technical terms that undergo a shift in meaning. And shifts in meaning can be considered semantic calques of Latin. There is a shift in meaning, for instance, when Ælfric uses ateorigendlic to render Lat. defectivus 'defective':

Sume word syndon gehatene DEFECTIVA, pæt synd ateorigendlice, forðan ðe hi ateoriað on sumere stowe. Ferio ic slea næfð nænne PRAETERITVM PERFECTVM, butan hit nime of oprum worde ðæs ylcan andgites: percutio ic slea, percussi ic sloh.

(Some verbs are called DEFECTIVA, that is to say defective, because they lack certain forms. Ferio 'I strike' has no PRAETERITVM PERFECTVM of its own, but borrows it from another verb with the same meaning: percutio 'I strike', percussi 'I struck'.) (Gneuss \& Zupitza 2001: 203; translation mine)

Ateorigendlic derives from the intransitive verb ateorian defined above. The adjective means 'failing, fleeting, perishable' and it so happens that Ælfric uses it in one of his homilies:

Seo yld is geteald to æfnunge ðises ateorigendlican middaneardes.

(That age is considered as the evening of this fleeting world. [BTS, s.v. ateorigendlic])

From 'failing, fleeting' to 'defective' one observes a semantic shift - corresponding to a narrowing of meaning indicating the transfer of ateorigendlic from non-technical vocabulary to grammatical terminology.

Ateorigendlic is no isolated case: the adjective ðylc (found in the Grammar as ðyllic) means 'such', but in its metalinguistic use refers to what belongs to the same paradigm (as another item under consideration). Anfeald means 'simple, peculiar, singular', but as a technical term it has an underextended meaning: 'simple' applies only to the form of words, in contrast to 'compound'; 'singular' refers only to the grammatical category of number and is then antonymous with 'plural'. The noun cwide (which has the variant form cwyde in the text) has the rather vague meaning of 'the expression of a thought', which accounts for the many different translations of the technical term, from 'word' to 'discourse', to 'sentence' and 'words'. Tid and tima have first and foremost the meaning of 'time', with all the semantic distinctions of time. But both also have a grammatical sense, which comes last in the entry for tid in BTS ('tense') and last but one in that for tima ('time of pronouncing a syllable, quantity'), a position which reflects the underextended meaning these items have when used metalinguistically. Contrary to the previous words, geicendlic 'adjective' is only a technical term, but a narrowing of meaning can be observed between the derivative and the original verb geican 'increase, add, enlarge': geicendlic represents a semantic narrowing, from 'added' to 'said of a noun added to another noun'. 
Had (Lat. persona), cynn (Lat. genus), name (Lat. nomen), word (Lat. verbum), hiw (Lat. schema, figura) and fyll (Lat. declinatio) are yet other instances of semantic shift.

Whether the terminology coined by Ælfric, by loan translation or other means, is meant to replace the Latin one and to be regularly used in the classroom is a nice question. Are his English terms real technical terms or rather glosses, "explanatory renderings of the Latin terms?" (Hurt 1972: 111). There is no clear-cut answer to this, especially as there is no way of ascertaining what exactly in the vernacular terminology is original with Ælfric and what antedates him, what was already conventional in the classroom practice of his day (Hurt 1972: 110-11; Law 1997: 214-15).

Yet, there exists a particular set of terms that seem to function as glosses to the Latin technical items, namely those formations which are either loan translations (element-by-element translation is the kind of lexical glossing commonplace in late Anglo-Saxon manuscripts) or loan renditions of Latin words, e.g.: OE wordes gefera 'adverb' (lit. 'companion to the verb'), ðas naman speliend 'pronoun' (lit. 'representing the noun') or again weaxan on genitivum 'be imparisyllabic' (lit. 'increase in the genitive'). In this connection, most of the "TRIGINTA DIVISIONES GRAMMATICAE ARTIS" (the thirty divisions of grammar) listed in the last section of the Grammar receive a vernacular equivalent in the form of incredibly unwieldy phrases which it is difficult to consider plausible technical terms. They rather look like "explanations of the Latin terms of the kind that a good teacher would provide to help his students understand and remember the new terms, not replacements for them" (Hurt 1972: 111). For instance, the Latin word ethimologia, inherited from Greek (lit. 'the study of the true sense of a word'), is rendered by OE namena ordfruma and gescead 'origin and shade [of meaning] of the nouns'. Other examples include Lat. barbarismus, rendered by $\mathrm{OE}$ anes wordes gewemmednys (lit. 'pollution of a word') or Lat. solocismus (lit. 'speaking [Greek] like the people of Soloi'), rendered by miscweden word on endebyrdnysse pare raedinge of Jam rihtan crafte 'sequence of words wrongly used in a text in consideration of correct speech'.

\section{CONCLUSION}

Following Swiggers, I have assumed here that between Greek and Latin grammar there is no real continuity. What about the relationship between the medieval English scholar Ælfric and the Imperial grammatici that he drew upon, Donatus and Priscian?

I have noted the transmission of a descriptive apparatus, at which level discontinuity appears in the partial re-organisation of the treatise so as to gain coherence and pedagogical efficiency, in the Christianisation and Anglicisation of the exemplification, in the systematic translation of Latin items into English and in the coinage of a vernacular grammatical terminology. Yet in the most important form of discontinuity, i.e. in Elfric's decision not to use Latin as the medium of a Latin grammar, several elements point to a continuity, such as the technical terms being Latin loan words or calques of Latin words or again functioning as glosses to Latin words. And even in his decision to use a vernacular, Ælfric may not be as original as all that:

The enormous variety of surviving Old English glosses to Latin texts testify that translation into the vernacular was a common learning tool (e.g. Page 1982). Thus it may well be that Ælfric's Excerptiones, in presenting Latin grammar through the medium of Old English, was not an innovation in teaching, but merely an innovation in written composition. (Bayless 1993: 75)

I have also noted the transmission of a conceptual framework. The facts taken into consideration are those dealt with by Donatus and Priscian, and they are analyzed with the help of the self-same concepts: Ælfric does not 
introduce new concepts into the description, nor does he elaborate or refine those transmitted by the grammatical tradition. Like his predecessors, the Carolingian grammarians (Holtz 1988), Ælfric shuns novelty, either because, as Vivien Law says, originality for originality's sake was unknown in the Middle Ages (Law 1997: 127), or because, as Giulio Lepschy says, the ars grammatica left by the classical tradition "was destined to be accepted as the most lucid and incisive instrument of intellectual penetration" (Lepschy 1994: 140, quoted above).

It might be interesting to extend these reflections by studying the transmission process between the Irish scholarly tradition and Ælfric. The Excerptiones de Prisciano descended from a text with an Irish pedigree and the scholarship of the Irish masters is said to have left distinctive marks on its glossing (Porter 2002: 15). If we accept that the main source for Ælfric's Grammar was the Excerptiones, then the Irish tradition is to be expected to have borne more or less directly on the writing of the Grammar.

\section{REFERENCES}

Bayless, M. (1993). Beatus quid est and the Study of Grammar in Late Anglo-Saxon England. In V.A. Law (Ed.), History of Linguistic Thought in the Early Middle Ages (pp. 67-82). Amsterdam and Philadelphia: John Benjamins.

Bender-Davis, J.M. (1985). Alfric's Techniques of Translation and Adaptation as Seen in the Composition of his Old English 'Latin Grammar'. Unpublished PhD dissertation, Pennsylvania State University.

Crépin, A. (1985). Dieu, le monde et moi d'après les exemples de la Grammaire d'Ælfric. Les Cahiers de Fontenay, 39/40, 79-93.

Gneuss, H. (1990). The Study of Language in Anglo-Saxon England. Bulletin of the John Rylands University Library of Manchester, 72, 3-32.

Hill, J. (2007). Elfric's grammatical triad. In Patrizia Lendinara, Loredana Lazzari and Maria Amalia D'Aronco (Eds.), Form and Content of Instruction in Anglo-Saxon England in the Light of Contemporary Manuscript Evidence (Textes et Études du Moyen Âge 39) (pp. 285-307). Turnhout: Brepols.

Holtz, L. (1981). Donat et la tradition de l'enseignement grammatical. Etude et édition critique. Paris: C.N.R.S. (1988). Les innovations théoriques de la grammaire carolingienne. Peu de choses : pourquoi ? In I. Rosier (Ed.), L'héritage des grammairiens latins de l'Antiquité aux Lumières (pp. 133-45). Paris: Société pour l'Information grammaticale.

Hurt, J. (1972). Alfric. New York: Twayne Publishers.

Lapidge, M. et al. (Eds.). (1999). The Blackwell Encyclopedia of Anglo-Saxon England. Malden, Oxford and Victoria: Blackwell Publishing.

Law, V.A. (1986). Late Latin Grammars in the Early Middle Ages: a Typological History. Historiographia Linguistica: International Journal for the History of Linguistics, 13(2-3), 365-80.

(Ed.). (1993). History of Linguistic Thought in the Early Middle Ages. Amsterdam and Philadelphia: John Benjamins (Amsterdam Studies in the Theory and History of Linguistic Science, series III: Studies in the History of the Language Sciences 71).

(1997). Grammar and Grammarians in the Early Middle Ages. London and New York: Longman.

Lepschy, G. (Ed.). (1994). History of Linguistics II: Classical and Medieval Linguistics. London and New York: Longman. 
Menzer, M.J. (1996). Donatus Anglice: AElfric's 'Grammar' and the Making of the English Language. Unpublished PhD Dissertation, University of Texas, Austin.

— 1999. Elfric's Grammar: Solving the Problem of the English-Language Text. Neophilologus, 83(4), 637-52.

, 2004. Elfric's English Grammar. Journal of English and Germanic Philology, 103(1), 106-124.

Porter, D.W. (1994). The Latin Syllabus in Anglo-Saxon Monastic Schools. Neophilologus, 78(3), 463-82.

(Ed.). (2002). Excerptiones de Prisciano. Cambridge: Brewer (Anglo-Saxon Texts 4).

Shook, L.K. (1939). Alfric's Latin Grammar: a Study in Old English Grammatical Terminology. Unpublished PhD dissertation, Harvard University.

Swiggers, P. (1995). L'héritage grammatical gréco-latin et la grammaire au Moyen Age. In A. Welkenhuysen, H. Buaet and V. Verbeke (Eds.), Mediaeval Antiquity (Mediaevalia Lovaniensia, series I, studia 24) (pp. 159195). Louvain: Presses Universitaires de Louvain.

Toupin, F. and Mensah M. (2005). La Grammaire d'Alfric : traduction et commentaire linguistique. Paris: AMAES (Publications de l'AMAES 27).

Williams, E.R. (1958). Ælfric's grammatical terminology. PMLA, 73, 453-62.

Zupitza, J. (Ed.). (1880). AElfrics Grammatik und Glossar. Berlin: Weidmannsche Verlagsbuchhandlung. (Sammlung englischer Denkmäler in kritischen Ausgaben 1).

New edition: Gneuss, H., Zupitza J. (Eds.). (2001). Berlin: Weidman. 